\title{
Rediscovery of the strange Costa Rica toad, Crepidius epioticus Cope
}

\author{
By \\ Jay M. Savage* and Arnold G. Kluge*
}

(Received for publication January 28, 1961)

In 1875, Edward Drinker Cope (3) described as Crepidius epioticus a peculiar toad collected by William M. Gabb from the Atlantic slopes of Cerro Kámuk (Pico Blanco), Provincia de Limón, Costa Rica. The single known specimen was taken at an elevation of approximately 5000 feet (1524 meters) in the Wet Subtropical Forest Zone of Holdridge (7 and 8). The holotype was 35 $\mathrm{mm}$ in standard length (snout-vent) and differed markedly from all other members of the family then known in the New World in having extensively webbed fingers and toes, combined with a unique pattern of cranial crests and absence of tympana and ostia pharyngea. Subsequent to its original collection, the species has never been retaken and the type specimen has been lost or destroyed (TAYLOR, 11). Most authors since COPE have placed the species in the genus Bufo (Boulenger, 1; Nieden, 9; Taylor, 11), but Gunther (6) referred it to Nannophryne because of the reduced auditory apparatus.

When the Departament of Biology of the University of Southern California initiated its program of study on the systematics, ecology and distribution of the herpetofauna of Costa Rica in 1959, a special effort was directed toward recollection of Cope's strange little toad. Instructions were given to the first field party, led by the junior author, to search out and bring back any peculiar-looking toads, which might represent Crepidius epioticus. The 1959 field party was in Costa Rica from March 6 to August 26. No toads similar to C. epioticus had been taken during the first four months of intensive work and we had almost given up hope of obtaining any examples. Then on July 17, the junior author, working alone near La Suiza, Provincia de Cartago, at El Silencio de Sitio Mata on the Finca of Don Juvenal Valerio R., captured a single small toad marked with dark blue on a gray ground color. The toad was captured as it hopped along

* Department of Biology, University of Southern California, Los Angeles 7, California. 
the wet forest floor during intermittent showers. It was immediately realized that the brightly colored toad was the long-sought-after epioticus. Two days later on July 19, about two hundred yards from the place where epioticus was collected on the 17th, three additional examples, one juvenile and two subadult females, were taken by Robert J. Lavenberg and the junior author. One of the larger specimens was the same general color as the toad collected two days before but the other was bright orange with dark blue-black markings. The juvenile lacked obvious blue or orange coloration. All specimens were collected between 10:00 A.M. and noon.

The four toads from La Suiza have proven on further study to match closely the original description by Cope in all but trivial details and are certainly conspecific with his specimen (figs. 1-4). The new locality for epioticus is 55 miles $(84 \mathrm{~km}$.) northwest of the type locality on Cerro Kámuk and lies at an elevation of 3650 feet (1115 meters) in the Wet Subtropical Forest belt of HoldRIDGe (7). Other amphibians collected in the same area include: Eleuthe. rodactylus caryophyllaceus, E. gollmeri, E. ranoides, E. rugosus, Microbatracylus persimilis, M. rearki, M. polyptychus, M. underwoodi, Bufo coniferus, Phyllomedusa lemur and Rana warschewitschii.

\section{STATUS OF THE GENUS CREPIDIUS.}

The extremely peculiar external charateristics of the type specimen are confirmed in the new material. No other known American bufonid has a combination of webbed fingers and toes; absence of auditory apparatus; cranial crest reduced to canthals, supraorbitals, supratympanics, reduced postorbitals and incomplete parietals; the bulbous supratympanic crests continuous with the very small rounded parotoid glands and the blue or orange coloration found in our subadult examples. On superficial examination these bufonids resemble some of the more toad-like Atelopus, but are not to be confused with members of the Atelopodidae, all of which lack cranial crests and parotoid glands.

Detailed study of internal characteristics of the Costa Rican form, based on a cleared and stained example, dissection of a second specimen and radiographs, futher substantiates the unique nature of the species. Internal structures fully support allocation of the form to the family Bufonidae. It possesses an arciferal pectoral girdle, eight procoelous presacral vertebrae, a free coccyx with two condyles, expanded sacral diapophyses and Bidder's organs. The species further agrees with other members of the family in lacking teeth.

TiHeN (12) has recently surveyed the characteristics of the genera of the family Bufonidae and described two new genera from Africa. A review of his data and comparison of our specimens of epioticus with American buforiids convinces us that this species deserves recognition as a distinct genus. Although most closely allied to Bufo among the ten genera considered valid by Tinen, Crepidius is unique among American toads in the structure of the coccyx (fig. 5) and the phalangeal formulae. These two salient features together with others found 
in different combinations elsewhere in the family lead us to redescribe this strange and rare genus.

\section{Crepidius Cope, 1875.}

\section{Monotype: Crepidius epioticus Cope, 1875.}

Diagnosis: A genus of bufonid toads differing from its closest relative $B$ ufo in having: a greatly reduced palatine (fig. 6); a markedly expanded coccyx; phalangeal formula of $1-2-3-2$ for the hand and $1-2-2-4-2$ for the foot; no adductor longus muscle; and no adductor mandibulae posteriori subexternus muscle(Starrett, 10). It differs from the genera Nectophrynoides, $A n$ sonia, Pseudobufo, Wolterstorffina, Mertensophryne, Pelophryne, Laurentophryne and Nectophryne in having cranial crests which they lack. In addition Crepidius may be distinguished from the last four genera in having eight presacral vertebrae while they possess only seven, and from the first six in having a reduced palatine. Crepidius differs from Pedostibes in lacking an auditory apparatus (present in the latter genus) and in having the tips of the phalanges unexpanded (expanded in Pedostibes).

Definition: Toads characterized by the following combination of significant features: eight presacral vertebrae; no fusion of cervical and second presacral vertebrae; sacrum and coccyx not fused together, the coccyx greatly expanded laterally, fig. 5); no auditory apparatus (lacks tympana, columellae and ostia pharyngea); no ammosternum; tips of phalanges not expanded, phalangeal formula of hand $1-2-3-2$ of foot $1-2-2-4-2$; no subdigital lamellae; tensor fascia latae muscle not elongate; no adductor longus muscle; and no adductor mandibulae posteriori subexternus (see StARrETt, 10).

\section{Crepidius epioticus Cope, 1875.}

Crepidius epioticus Cope, 1875: 97 (figs. 1-4) 1877: pl. 23, fig. 2; Brocchi, 1882: 95; Cope 1887: 11.

Bufo epioticus Boulenger, 1882: 326; Nieden, 1923: 135; Taylor, 1952: 604, fig. 2.

Nannopbryne epiotica Gunther, 1901: 257.

Holotype: A subadult of unknown sex, $35 \mathrm{~mm}$ in standard length; presumably lost (TAYLOR, 11).

Type Locality: Cerro Kámuk (Pico Blanco), Provincia de Limón, Cosia Rica, altitude 5000 feet ( 1524 meters).

General Characteristics: Head, viewed from above, wedge shaped, broader than long. Snout short, pointed. Canthus rostralis marked by a distinct crest, shorter than interorbital width. Median portion of snout depressed, roughly V-shaped with open end posteriory directed. Canthal ridge ending as a swelling above nostril. A ridge of warts running vertically upward from lip on center of snout. Supraorbital crest very high, smooth, continuous with canthal ridge; extending in essentially a straight line from canthal region to above middle of 
upper eyelid where it thickens noticeably and curves abruptly around posterior margin of upper eyelid. An extremely thickened bulbous supratympanic ridge, continuous with supraorbital crest; extending posteriorly to eye to meet anterior margin of parotoid gland. Parietal crest represented by small irregular ridge extending from posterior region of supraorbital crest toward dorsal midline, more or less parallel to pretympanic ridge. Area between supraorbital crests flat with a few rounded warts. Distance between crest, interorbital width, less than one-third width of head. A faint occipital depression demarcates posterior margin of skull. Upper eyelids much longer than wide; length about one-third head length; equal to interorbital width; warts on eyelid large but smooth.

In profile, snout slopes forward anteriorly from eye to tip of snout where it turns at right angles and continues to upper lip. Tip of snout projects somewhat beyond mouth; marked by a single median ridge with a large wart at its uppermost extent. Nostrils round, with a free flap of tissue along posterior margin, small, located well back from tip of snout in a swollen area just below canthal ridge; separated from each other by a distance equal to distance from eye to nostril. Orbit longer than high, greatest diameter about one-third head width. Eye protected above by a warty upper eyelid to which is attached, underneath, a delicate membrane (the true eyelid). Lower eyelid a smoot membrane which meets upper eyelid, when closed, to form a horizontal slit. Membranes almost transparent. Upper free margin of lower eyelid edged with light and dark pigment. Pupil horizontally elliptical. Distance from tip of snout to eye less than diameter of eyc. No tympanum; tympanic area smooth with a few small rounded warts. Mouth originating directly below middle of supratympanic crest. Upper jaw slightly incised at symphysis, almost straight. Lower jaw inferior with a slight median protuberance. Cranial crests on sides of head completely absent except for obscure suggestion of a postorbital ridge. Side of head rather smooth with only a few scattered warts.

Parotoid glands very small, broader than long, in direct contact with supratympanic crest, separated from each other by a distance approximately three times their length. smooth.

Dorsum covered with numerous smooth warts, rather widely separated, replaced laterally by somewhat larger and more pointed warts. A distinct lateral ridge of warts running posteriorly from posterior margin of parotoid to about one-third the distance between axilla and groin. Numerous small pointed warts in lateral area below ridge. A faint mid-dorsal groove usually apparent. Anus surrounded by numerous small pointed warts.

Anterior limbs short, about half as long as standard length, covered with small spiny warts on all surfaces. Fingers four in number. First finger shortest, second and fourth fingers about equal in length, third finger 'much longer than any other three, its greatest length exceeding the interorbital width. A smooth thick fleshy web between all fingers. Only tips of first and second fingers free of web. Web between second and third fingers extending to base of second phalanx of the latter; web between the third and fourth fingers of about same extent as between second and third, tips of fingers free of webbing. 
Upper surface of hand covered with very small pointed warts except for region at base of third and fourth fingers where larger pointed warts are present. Thenar tubercle (inner palmar tubercle) of hand moderate, about one-half as large as outer palmar tubercle. All tubercles on under surface small and poorly developed.

Hind limbs moderate, a little longer than standard length. Tibio-tarsal articulation reaching almost to axilla when limb is brought forward along body. When legs are folded at right angles to body, heels are widely separated. All surfaces of leg covered with spiny warts; two obscure metatarsal tubercles, outer the largest. Lower surface of foot very smooth. First, second, and fourth toes about equal in length, third toe longest. Length of third toe less than least distance between parotoids. A smooth thick fleshy web between all toes. First, second and fourth toes almost fully webbed. Third toe webbed to base of second phalanx.

Throat covered with well developed pointed warts. Ventral surface of body densely covered by small pustular pointed warts.

Choanae large, ovoid, opening into mouth at a point anterior to orbit. Tongue elongate, not notched.

Measurements: The standard lengths of the three adult specimens are $23.4 \mathrm{~mm}$ (male), $26.3 \mathrm{~mm}$ (female) and $29.1 \mathrm{~mm}$ (female). Respectively, as percentages of standard length, head length 29.0, 33.1 and 31.9; head width 33.6, 38.1 and 39.7; diameter of eye 14.2, 15.4 and 14.2; snout length 12.8, 13.9 and 13.1 ; interorbital width $9.0,11.0$ and 9.4 ; length of parotoid $8.3,9.0$ and 8.1; greatest width of parotoid 8.6, 9.2 and 8.8; least distance between parotoids 21.6, 22.2 and 20.4; greatest distance between parotoids 32.4, 26.9 and 35.8; length of arm 44.3, 48.5 and 43.4; length of hand 21.8, 23.3 and 21.6; length of third finger 9.8, 11.4 and 10.3; length of leg 116.7, 112.1 and 111.2; length of tibia 35.3, 35.9 and 37.7; length of foot 34.9, 34.3 and 33.2; length of longest toe (third) 17.1, 16.2 and 15.0.

Percentages were not calculated for the young specimen which had a standard length of $7.1 \mathrm{~mm}$.

Coloration: Ground color of head, back and upper surfaces of limbs highly variable, grayish-black (bluish in life) to orange. A light interorbital band and a vague dark bar across the center of upper eyelids. Dark triangular mark on tip of snout, its base bordering lip edge and its apex reaching level of nostrils. Large dark mark immediately below and in contact with eye, extending to lip. Upper lip much lighter in color than lower. Cranial crests lighter in color than surrounding area. Parotoid glands variable, grayish-brown to orange with black star-shaped chromatophores. Large distinct light area following each parotoid gland. Dark stripe runnning from parotoid gland to groin immediately below line of enlarged lateral body warts. Dorsal surfaces of limbs banded with black. When hind limbs are drawn up next to body in natural position, dark bands are continuous across thigh, foreleg and ankle. Highly variable dark dorsal pattern, more obvious on specimens with lighter ground color. In life light ground color bluish-gray or bright orange, all dark markings with bluish 
cast ranging from blue-black, in examples with orange ground color, to bright deep blue in specimen with blue-black ground color. Ventral surfaces of throat and body uniform light brown, with bluish tone in life. Ventral surfaces of appendages flesh color (orange in life), flecked with dark pigmentation. Ventral surfaces of hands and feet similarly flecked, but, fleshy tubercles devoid of dark pigment. Apexes of pustules of body and appendages much lighter than surrounding color. Single young specimen exhibits white post-parotoid spot, appendicular bands and white tipped pustules of adults. Its ventral surfaces show very little pigmentation.

Distribution: Known from only two localities in the Wet Subtropical Forest belt on the Atlantic slopes of Costa Rica (fig. 7).

Discussion: This strange little toad appears to be restricted to undisturbed portions of Wet Subtropical Forest. Very likely its rarity in collections is due to the extensive cultivation in this type of forest in Costa Rica with consequent destruction of all but a few isolated virgin sections. Situations similar to those on Cerro Kámuk and at our La Suiza locality are few and widely scattered on the Atlantic slope, but it is entirely possible that additional examples of Crepidius will be taken further to the northwest in appropriate forest stands along the Atlantic slope of the Cordillera Central. The original distribution of Wet Subtropical Forest in Costa Rica before the massive agricultural activities of the nineteenth and twentieth centuries are indicated on the accompanying map (fig. 7). There is no particular reason to expect Crepidius epioticus to occur on the Pacific slopes nor as far north as the Cordillera de Guanacaste.

The Costa Rican genus is most closely related to Bufo within the family Bufonidae. In contrast to Crepidius (characters in parentheses) the latter group has the palatine meeting both maxilla and ethmoid (palatine reduced, meeting neither maxilla nor ethmoid); coccyx not or very slightly expanded (greatly expanded); phalangeal formula of hand 2-2-3-3, foot 2-2-3-4-3 (hand 1-2-3-2, foot 1-2-2-4-2); an adductor longus muscle (no adductor longus); an adductor mandibulae posteriori subexternus (no adductor mandibulae posteriori subexternus).

Crepidius differs principally from Bufo in characteristics that suggest evolutionary advance through reduction (palatine, phalangeal formulae, and muscle characters). The peculiar coccyx suggests specialization over the generalized Bufo condition. Tentatively, it appears logical on the basis of this evidence to regard Crepidius as an advanced Bufo derivate not obviously related closely to any living species of the latter genus.

The unique extensively webbed hands and feet, the bulbous supratympanic cranial crest and their relation to the small rounded parotoid glands and the bright coloration immediately distinguish Crepidius epioticus from all known American Bufo.

\section{ACKNOWLEDGEMENTS}


Mr. Robert J. Lavenberg, and Mrs. Priscilla H. Starrett, all of the University of Southern California. We greatly appreciate their assistance. Mrs. Jean B. Kluge prepared the illustration (figs. 1 to 4 ) of Crepidius.

The fieldwork in Costa Rica was made possible by a grant (G-6089) from the National Science Foundation.

\section{SUMMARY}

The peculiar Costa Rican bufonid Crepidius epioticus Cope, is redescribed on the basis of newly collected material. The validity of the genus is confirmed by these specimens. Association of the species with undisturbed portions of Wet Subtropical Forest is indicated.

\section{RESUMEN}

El extraño sapo costarricense Crepidius epioticus Cope, 1875, que se describió oríginalmente de un ejemplar de las estribaciones atlánticas del Cerro Kámuk, se volvió a recoger en El Silencio de Sitio Mata, cerca de La Suiza, Provincia de Cartago. Cuidadoso estudio de los cuatro ejemplares nuevos verifica completamente el género Crepidius que está en la familia Bufonidae. El tipo, único ejemplar conocido, se ha perdido y por eso se vuelve a definir el género y se describe en gran detalle la especie. La escasez de este sapo extraordinario sugiere que se limita a lugares del bosque virgen subtropical muy húmedo de Costa Rica.

\section{LITERATURE CITED}

1. Boulenger, G. A.

1882. Catalogue of the Batrachia Salientia s. Ecaudata in the Collection of the British Museum (Natural History). xvi +503 pp, pls. 1.30.

2. BROCCHI, M.

1882. Etude des Batraciens de L'Amérique Centrale. In Mission Scientifique au Mexique et dans l'Amérique Centrale (Recherches Zoologique's), pt. 3, sect. 2: 1-122, pls. 1-21.

3. COPE, E. D.

1875. On the Batrachia and Reptilia of Costa Rica. Journ. Acad. Nat. Sci., Philadephia, ser. 2, 8(4): 93-154 (letterpress).

4. Cope, E. D.

1877. The Batrachia and Reptilia of Costa Rica (atlas). Journ. Acad. Nat. Sci., Pbiladelphia, ser. 2, 8: pls. 1-6.

5. COPB, E. D.

1887. Catalogue of Batrachians and Reptiles of Central America and Mexico. Binll. United States Natl. Must, 32: 1.98, 
6. Gunther, A. C. L. G.

1901. Biologia Centrali-Americana. Reptilia and Batrachia, 1885-1902: $\mathrm{i}+\mathrm{xx}$; $1-326$, pls. $1-76$.

7. Holdridge, L. R.

1953. La Vegetación de Costa Rica. In E. W. Trejos and A. Archer, Ailas Estadístico de Costa Rica, 1953: 1-114.

8. HOLDRIDGE, L. R.

1959. Mapa Ecológico de Costa Rica, A. C., In Climatic limits of Cacao, Coffee and Rubber. Inter-American Institute of Agricultural Sciences, Turrialba, Costa Rica.

9. NIFDEN, F.

1923. Das Tierreich. Lief. 46; Anura I. xxxii, + 584 pp., figs. 1-380.

10. Starkett, P. H.

1961. A redefinition of the genus Smilisca Cope. Copeia, 1960 (4): 300-304, 3 figs.

11. TAYLOR, E: H.

1952. The frogs and toads of Costa Rica. Univ. Kansas Sci. Bull., 35 (5): 577-942.

12. TIHEN, J. A.

1960. Two new genera of African bufonids, with remarks on the phylogeny of related genera. Copeia, 1960, (3): 225-233.

Figs. 1 - 4: Crepidius epioticus Cope, subadult female. 1. Lateral view of head. 2. Dorsal view. 3. Ventral view of left hand. 4. Ventral view of left foet. 


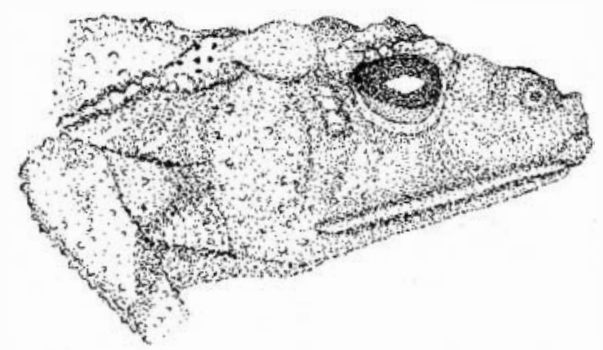

FIG. I
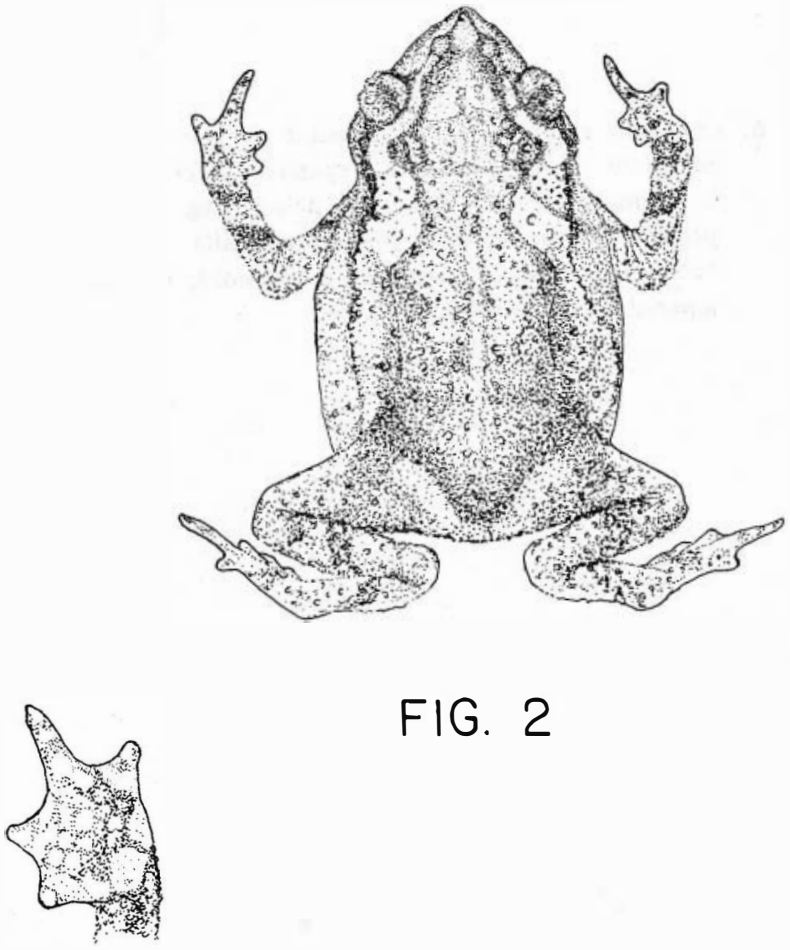

FIG. 2

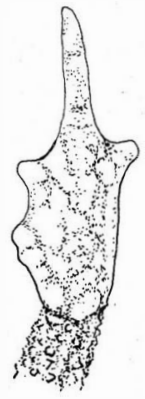

FIG. 3

FIG. 4 
Figs. 5 - 6: Crepidius epioticus Cope. Subadult female. 5. Dorsal view of coccyx; note expanded lateral areas. 6. Ventral view of bones of palatal regions; pm, premaxilia; $\mathrm{m}$, maxilla; $\mathrm{sm}$, septomaxilla; $\mathrm{pv}$, prevomer; $n$, nasal; $p$, palatine; e, ethmoid; fp, frontoparietal; ps, parasphenoid. 


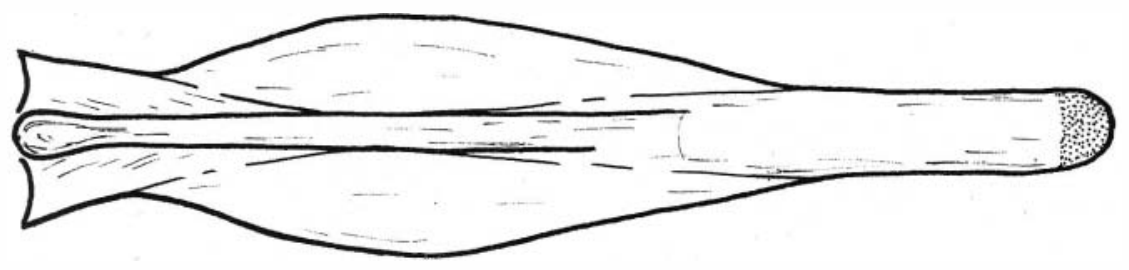

FIG. 5

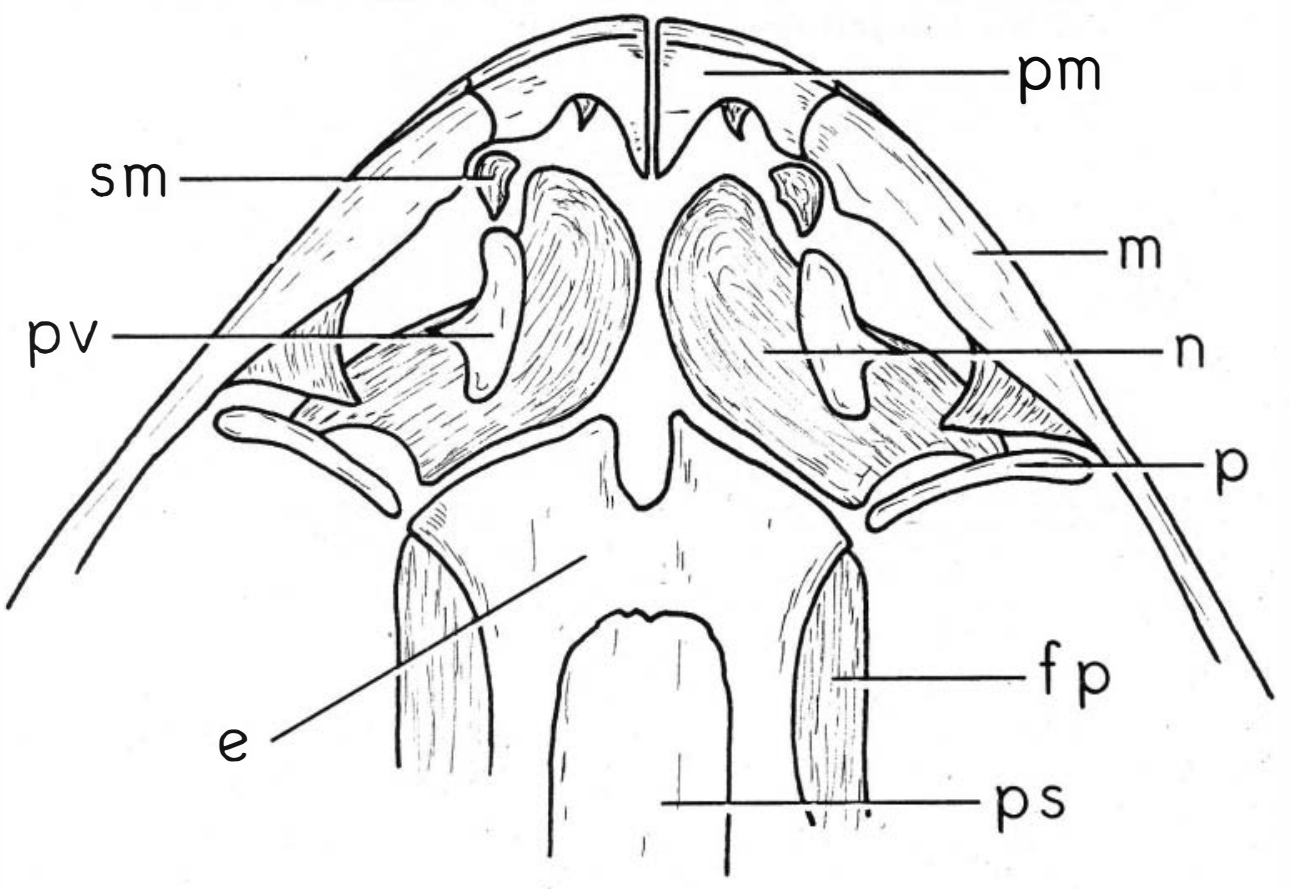

FIG. 6 
REVISTA DE BIOLOGIA TROPICAL

Fig. 7: Distribution of Crepidius epioticus Cope. Stippled areas indicate original extent of Wet Subtropical Forest in Costa Rica. 


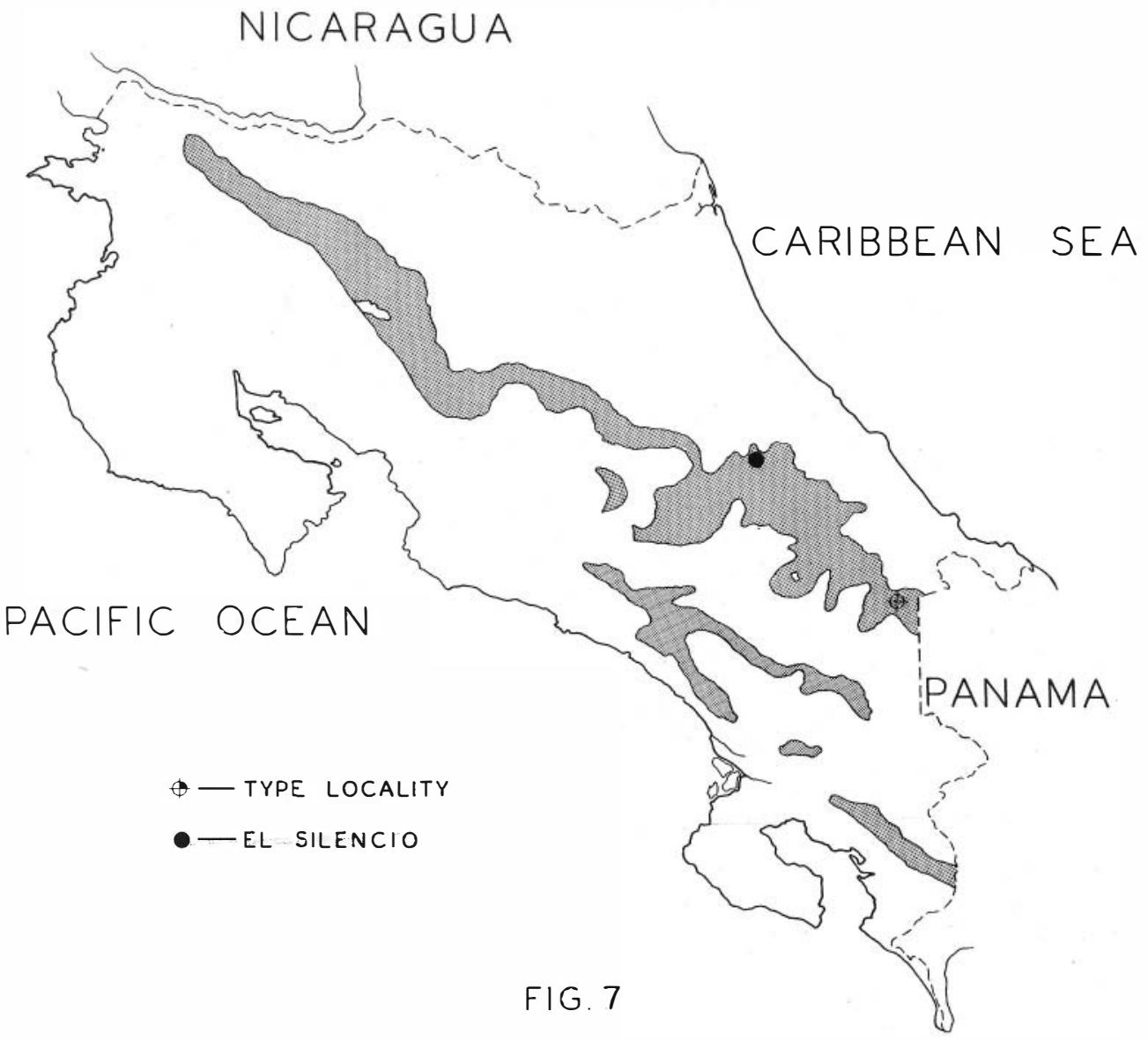

